\title{
KINERJA USAHA TERNAK SAPI PERAH DI KELURAHAN KEBON PEDES, KOTA BOGOR
}

\author{
Gabriella Stephanie Gultom ${ }^{1)}$, dan Suharno ${ }^{2)}$ \\ ${ }^{1,2)}$ Departemen Agribisnis, Fakultas Ekonomi Manajemen, Institut Pertanian Bogor \\ ${ }^{1)}$ riel.cute@ymail.com
}

\begin{abstract}
Dairy cows is one of animal husbandry that produce milk. In Indonesia, there is a gap between milk demand and its production that offers chance of animal husbandry business. Bogor is a city in West Java that has numbers of family relying their family's livelihood on animal husbandry business. There are two dairy cow farmers groups that is still operating in Bogor, Kelompok Ternak Maju Terus ('Maju Terus' Group) and Kelompok Ternak Sumber Makmur ('Sumber Makmur' Group). The objectives of this research are to analyze the determinant factors of milk production and business performance in both farmer groups. The production function, income approach and $R / C$ ratio analysis are used to obtain the research objectives. The result shows that determinant factors that statistically significant are the number of productive cows, the amount of feed both green feed and 'waste' feed, while concentrate is not significant. The farmer group performance of 'Maju Terus' is better than 'Sumber Makmur' where the R/C ratio is higher. The farmers should increase the number of dairy cow ownership, the amount of feed and 'waste' feed, therefore milk production of dairy cows will increase and improve the income of farmers.
\end{abstract}

Keyword(s): dairy cow, performance, production function, income approach, $R / C$ ratio

\begin{abstract}
ABSTRAK
Sapi perah merupakan salah satu hewan ternak yang menghasilkan susu. Di Indonesia, masih terdapat gap antara permintaan dan prodduksi susu sehingga memberikan kesempatan yang baik untuk bisnis peternakan. Kota Bogor adalah salah satu wilayah di Jawa Barat yang sebagian dari masyarakatnya masih mengusahakan sapi perah sebagai penghasilan utama keluarga. Terdapat dua kelompok ternak yang masih aktif melakukan usaha sapi perah untuk menghasilkan susu segar. Kelompok ternak tersebut adalah Kelompok Ternak Maju Terus dan Sumber Makmur. Tujuan penelitian ini adalah untuk menganalisis faktor yang mempengaruhi produksi susu dan kinerja kedua kelompok ternak. Fungsi produksi, analisis pendapatan dan $\mathrm{R} / \mathrm{C}$ ratio digunakan untuk memperoleh tujuan tersebut. Hasil dari penelitian ini menunjukkan bahwa faktor-faktor yang mempunyai pengaruh signifikan adalah jumlah sapi laktasi, jumlah pemberian pakan hijauan dan jumlah pemberian pakan ampas, sedangkan faktor konsentrat tidak mempunyai pengaruh nyata. Kinerja usaha ternak di Kelompok Ternak Maju Terus lebih baik dibandingkan Sumber Makmur karena tingkat pendapatan dan nilai R/C rasio lebih tinggi. Peternak harus meningkatkan jumlah kepemilikan sapi perah, pemberian pakan hijauan dan pakan ampas sehingga produksi susu sapi perah akan meningkat dan meningkatkan pendapatan peternak.
\end{abstract}

Kata Kunci: sapi perah, kinerja, fungsi produksi, pendapatan, $\mathrm{R} / \mathrm{C}$ rasio 


\section{PENDAHULUAN}

Sektor peternakan merupakan salah satu sektor yang berkontribusi terhadap Produk Domestik Bruto (PDB) di Indonesia. Kontribusi sektor peternakan terhadap PDB tahun 2012 sebesar $12,21 \%$ dan meningkat lagi tahun 2013 mejadi 12,59\% (BPS, 2014). Sektor ini masih dijadikan sebagai usaha untuk memenuhi kebutuhan hidup bagi masyarakat di Indonesia, tercermin dari populasi ternak yang dimiliki peternak setiap tahun semakin meningkat (Lampiran 1). Hal tersebut membuktikan bahwa usaha ternak menguntungkan untuk dijalankan.

Salah satu hewan ternak penghasil protein yang berasal dari susu adalah sapi perah. Permintaan akan susu terus mengalami peningkatan karena masyarakat semakin memiliki kesadaran akan kebutuhan nutrisi untuk tubuhnya. Produksi susu di Indonesia dari tahun ke tahun juga mengalami peningkatan. Pada tahun 2010 produksi susu sebesar 909.500 ton, tahun 2011 sebesar 974.700 ton, tahun 2012 mengalami penurunan menjadi 959.700 ton dan meningkat kembali pada tahun 2013 (angka sementara) yaitu sebesar 981.600 ton (Deptan, 2014). Namun, peningkatan hasil produksi susu masih lebih rendah dibandingkan dengan permintaan akan susu. Hal ini dapat dilihat dari konsumsi susu nasional yaitu pada tahun 2010 sebesar 3.173 .050 ton, kemudian meningkat tahun 2011 (angka sementara) menjadi sebesar 3.494 .810 ton dan mengalami penurunan tahun 2012 (angka estimasi) menjadi 2.738.510 ton (Ditjennak, 2014). Hal ini menunjukkan bahwa usaha sapi perah masih memiliki peluang untuk dilaksanakan.

Jawa Barat merupakan salah satu provinsi di Indonesia yang cocok sebagai pengembangan agribisnis sapi perah. Hal tersebut terlihat dari jumlah populasi sapi perah di Jawa Barat yang menempati urutan ketiga setelah Jawa Timur dan Jawa Tengah. Sedangkan produksi susunya menempati urutan kedua setelah Jawa Timur (Deptan, 2014).

Kota Bogor adalah salah satu wilayah di Jawa Barat yang sebagian dari masyarakatnya masih mengusahakan sapi perah sebagai penghasilan utama keluarga. Usaha ternak yang dulu pernah berjaya di Kota Bogor dan merupakan ikon dari susu murni terletak di Kelurahan Kebon Pedes. Namun peningkatan jumlah penduduk di Kota Bogor memberikan dampak pada usaha ternak tersebut. Pemerintah Kota Bogor telah berusaha merealokasi usaha peternakan di Kelurahan Kebon Pedes ke daerah Kawasan Usaha Peternakan (KUNAK) di Kecamatan Cibungbulang. Namun, peternak menolak rencana tersebut karena memiliki banyak kendala mulai dari modal untuk menyewa kandang, tenaga kerja dan pemasaran susu sapi. Alasan lainnya adalah peternak tidak mau meninggalkan kampung halaman serta warisan usaha turun temurun dari keluarganya.

Terdapat dua kelompok ternak yang masih aktif melakukan usaha sapi perah untuk menghasilkan susu segar. Kelompok ternak tersebut adalah Kelompok Ternak Maju Terus dan Kelompok Ternak Sumber Makmur. Pelaksanaan usaha ternak masih 
menggunakan cara tradisional yang didapatkan dari keluarga peternak. Peternakan sapi di Kelurahan Kebon Pedes tergolong pada peternakan sapi rakyat dimana kepemilikan sapi berkisar 1 sampai 9 ekor. Rata-rata kepemilikan sapi perah di kedua kelompok tersebut ialah 7 sampai 8 ekor per peternak sedangkan produktivitas rata-rata sebesar 9 sampai 10 liter perekor perhari. Atmakusuma (2012) dan Harmini et al. (2012) mengatakan bahwa produksi susu peternak Indonesia umumnya kurang dari atau sama dengan 10 liter perekor perhari, sekalipun menggunakan bibit sapi unggul yang sebenarnya mampu berproduksi 15 sampai 20 liter perekor perhari (Yusdja, 2005). Walaupun memiliki peluang yang tinggi untuk berusaha ternak sapi perah, namun skala usaha yang relatif kecil dan produksi susu yang rendah akan sangat berpengaruh terhadap kinerja usaha yang tercermin dari tingkat pendapatan atau keuntungan yang akan diperoleh.

Usaha ternak yang berhasil terlihat dari kinerja usaha yang baik dalam menghasilkan produksi susu yang optimal. Produksi susu yang optimal dipengaruhi oleh faktor-faktor produksi yang mendukungnya. Skala usaha ternak sapi perah di Kelurahan Kebon Pedes relatif kecil dan tergolong ke dalam peternakan rakyat. Sehingga hasil produksi susu sapinya juga relatif kecil. Kendala modal yang dialami peternak menjadikan mereka berusaha pada jumlah sapi laktasi yang rendah. Sapi laktasi yang dimiliki peternak di Kebon Pedes juga sering diperjualbelikan karena produksi susu yang dihasilkan rendah atau mencari sapi yang akan mempro- duksi susu untuk menjaga keberlangsungan produksi susu sapinya. Kendala pakan juga dialami peternak akibat dari tidak ada lahan untuk menanam hijauan sehingga pakan hijauan yang diberikan kepada sapi laktasi juga tidak optimal. Hal tersebut sangat berpengaruh kepada hasil produksi susu sapi perah tersebut.

Sudono (1999) mengatakan bahwa terdapat beberapa faktor yang mempengaruhi kualitas, kuantitas dan susunan susu adalah bangsa/rumpun sapi, lama bunting, masa laktasi, besarnya sapi, estrus (berahi), umur, selang beranak (calving interval), masa kering, frekuensi pemerahan, makanan dan tata laksana. Ako (2013) menyatakan bahwa ada dua faktor yang mempengaruhi produksi dan kualitas air susu yaitu faktor internal dan faktor eksternal. Pada faktor internal terdiri dari bangsa/ rumpun/ breed, keturunan, masa laktasi, umur, kondisi ternak dan ambing, siklus estrus (berahi) dan kebuntingan. Sedangkan faktor eksternal terdiri dari musim/iklim, interval pemerahan, lama masa kering, pengaturan calving interval, pemberian obatobatan, pemberian hormon, penyakit, pergantian pemerah dan makanan.

Anisa (2008) mendapatkan faktorfaktor yang mempunyai pengaruh nyata terhadap produksi susu sapi perah di wilayah kerja KPSBU Lembang Kabupaten Bandung adalah jumlah sapi laktasi dan ampas tahu. Berbeda halnya dengan Heriyanto (2009) dan Karuniawati (2012) menyatakan bahwa faktorfaktor yang mempengaruhi produksi susu sapi perah pada peternak adalah jumlah pemberian pakan konsentrat sapi berproduksi, jumlah pemberian pakan 
hijauan sapi berproduksi dan masa laktasi sapi yang berproduksi sedangkan faktor biaya usaha tidak berpengaruh nyata. Hal tersebut senada dengan pernyataan Alpian (2010) dan Apriani (2011) yang menyatakan bahwa faktor yang paling berpengaruh terhadap produksi susu pada sapi perah adalah pemberian pakan yaitu berupa pakan hijauan dan konsentrat. Karuniawati (2012) menambahkan fakor mineral, air dan penggunaan tenaga kerja sebagai faktor-faktor yang dapat meningkatkan produksi susu. Wahyudi (2014) mengatakan bahwa produktivitas (produksi susu sapi) akan mempengaruhi pendapatan peternak sapi perah.

Kinerja yang baik akan memberikan keuntungan yang baik bagi usaha ternak tersebut. Kinerja suatu usaha dikatakan baik dapat dilihat berdasarkan seberapa besar tingkat pendapatan yang diterima peternak dan seberapa besar tambahan pendapatan yang dihasilkan jika pengusaha tersebut menambah satu satuan biaya produksinya. Pertanyaannya adalah apa saja faktor-faktor yang mempengaruhi produksi susu sapi perah yang dipelihara oleh peternak di Kelurahan Kebon Pedes, Kota Bogor? Berdasarkan besarnya tingkat pendapatan dan rasio $\mathrm{R} / \mathrm{C}$, bagaimana kinerja peternak di Kelompok Ternak Maju Terus dan peternak di Kelompok Ternak Sumber Makmur pada lokasi yang sama di Kelurahan Kebon Pedes, Kota Bogor? Manakah kinerja yang lebih baik? Berdasarkan uraian tersebut, maka kajian kinerja usaha ternak sapi perah penting dilakukan untuk menjawab pertanyaan tersebut. Oleh karena itu penelitian ini bertujuan untuk menganalisis faktor- faktor yang mempengaruhi produksi susu di tingkat peternak di Kelurahan Kebon Pedes, Kota Bogor serta menganalisis kinerja peternak di Kelompok Ternak Maju Terus dan Kelompok Ternak Sumber Makmur di Kelurahan Kebon Pedes dalam usaha ternak sapi perahnya melalui pendekatan fungsi produksi, analisis pendapatan dan analisis rasio $\mathrm{R} / \mathrm{C}$.

\section{KERANGKA PEMIKIRAN}

\section{Konsep Produksi dan Fungsi Produksi}

Nicholson (2000) menjelaskan bahwa fungsi produksi merupakan hubungan matematik antara input dengan output. Semaoen dan Siti (2011) menyatakan bahwa fungsi produksi adalah hubungan antara output maksimum yang diperoleh dengan menggunakan sejumlah faktor produksi tertentu. Sedangkan Sudarsono (1995) dan Debertin (1986) mengatakan bahwa fungsi produksi adalah hubungan teknis yang mengubah input (faktor produksi) menjadi hasil produksinya (output). Fungsi produksi adalah sebagai berikut:

$$
\mathrm{Y}=\mathrm{f}\left(\mathrm{X}_{1}, \mathrm{X}_{2}, \mathrm{X}_{3}, \ldots, \mathrm{Xn}_{\mathrm{n}} \mid \mathrm{X}_{\mathrm{p}}\right)
$$

Keterangan:

$\mathrm{Y}=$ Hasil produksi (output)

$\mathrm{f}=$ Mentransformasikan faktor-faktor produksi ke dalam hasil produksi

$\mathrm{X} 1, \mathrm{X} 2, \mathrm{X} 3, \ldots, \mathrm{Xn}=$ Input variabel

$\mathrm{Xp}=$ Input tetap.

\section{Teori Pendapatan}

Penerimaan usahatani ialah hasil perkalian antara produksi yang diperoleh dengan harga jual (Soekartawi, 2002). Secara matematis total penerimaan atau total pendapatan (Total Revenue) dapat dirumuskan sebagai berikut: 


$$
\mathrm{TR}=\mathrm{Py} . \mathrm{Y}
$$

Keterangan :

$\mathrm{TR}=$ Total Revenue atau total penerimaan $(\mathrm{Rp})$

Py $=$ Price atau harga pasar (Rp)

$\mathrm{Y}=$ Output atau hasil produksi (satuan).

Total penerimaan yang dikurangi dengan total biaya yang dikeluarkan disebut dengan pendapatan bersih atau keuntungan (profit) yang diterima oleh petani ataupun pengusaha. Biaya tunai merupakan biaya yang dikeluarkan dalam bentuk tunai (uang). Sedangkan biaya non tunai (biaya diperhitungkan) merupakan biaya yang dikeluarkan petani /peternak bukan dalam bentuk uang tunai, tetapi diperhitungkan dalam perhitungan usahatani/ternak, seperti upah tenaga kerja dalam keluarga, penyusutan, biaya sewa lahan dan sebagainya. Pendapatan bersih atau keuntungan dapat dirumuskan sebagai berikut :

$$
\mathrm{Pd}=\mathrm{TR}-\mathrm{TC}
$$

Keterangan:

$\mathrm{Pd}=$ Pendapatan bersih atau keuntungan $(\mathrm{Rp})$

$\mathrm{TR}=$ Total penerimaan $(\mathrm{Rp})$

$\mathrm{TC}=$ Total biaya tunai dan non tunai $(\mathrm{Rp})$.

Moeheriono (2010) mengatakan bahwa kinerja atau performance merupakan gambaran mengenai tingkat pencapaian pelaksanaan suatu program kegiatan atau kebijakan dalam mewujudkan sasaran, tujuan, visi dan misi organisasi yang dituangkan melalui perencanaan strategis suatu organisasi.

Salah satu cara untuk mengukur kinerja usaha, selain dari pendapatan usahanya adalah dengan melihat rasio $\mathrm{R} / \mathrm{C}$ (Return Cost Ratio). Rasio R/C adalah perbandingan antara penerimaan dan biaya (Soekartawi, 2002).

\section{METODE PENELITIAN}

\section{Lokasi dan Waktu Penelitian}

Penelitian ini dilaksanakan di usaha ternak sapi perah pada dua kelompok ternak yaitu Kelompok Ternak Maju Terus dan Kelompok Ternak Sumber Makmur di Kelurahan Kebon Pedes, Kota Bogor. Pemilihan lokasi penelitian ini dilakukan secara sengaja (purposive) dengan pertimbangan bahwa Kelurahan Kebon Pedes merupakan salah satu sentra peternakan sapi perah di Kota Bogor. Kegiatan pengumpulan data dilaksanakan pada bulan Januari 2014 hingga bulan Maret 2014.

Jenis data yang dibutuhkan dalam penelitian ini adalah data primer dan data sekunder. Data primer berasal dari informasi tentang produksi susu pada satu sapi laktasi dengan pengambilan data "on the spot" di bulan Januari dan Februari 2015 dengan laktasi sapi berkisar antara laktasi ketiga dan keempat, total penerimaan dan total biaya untuk menghasilkan susu segar per ekor sapi laktasi yang diperoleh secara langsung dari 32 responden yang terdiri dari 19 orang peternak sapi perah pada Kelompok Ternak Maju Terus dan 13 orang peternak Kelompok Ternak Sumber Makmur di Kelurahan Kebon Pedes. Pengumpulan data primer dilakukan dengan menggunakan metode recalling kepada 32 peternak sapi perah di Kelurahan Kebon Pedes dan menggunakan kuesioner yang langsung dipandu oleh peneliti. Data sekunder berasal dari literatur-literatur terkait dengan topik penelitian yaitu berupa informasi tempat tinggal peternak, data- 
data tentang produksi dan konsumsi susu di Indonesia yang berasal dari buku, artikel, jurnal, data dari instansi seperti Dinas Peternakan, BPS dan sebagainya ataupun melalui pencarian data di internet. Pengumpulan data sekunder dilakukan dengan penelusuran pustaka-pustaka terkait baik melalui media cetak, internet serta mendatangi instansi terkait untuk memperoleh data yang dibutuhkan.

Fungsi produksi Cobb-Douglas merupakan salah satu fungsi yang paling sering digunakan untuk analisis produksi pada usahatani. Menurut Soekartawi (2002) fungsi produksi Cobb-Douglas merupakan suatu fungsi atau persamaan yang melibatkan dua atau lebih variabel. Varibel yang dijelaskan disebut sebagai variabel dependen (Y) dan variabel yang menjelaskan disebut sebagai variabel independen (X). Variabel dependen berupa output sedangkan variabel independen berupa input. Adapun persamaan matematis mengenai fungsi produksi Cobb-Douglas dengan $\mathrm{n}$ variabel bebas secara umum adalah sebagai berikut (Soekartawi et al., 1986):

$$
\mathrm{Y}=\mathrm{a}_{\mathrm{0}} \mathrm{X}_{1}^{\mathrm{a} 1} \mathrm{X}_{2}{ }^{\mathrm{a} 2} \ldots \mathrm{X}_{\mathrm{n}}^{\mathrm{an}}
$$

Keterangan:

$\mathrm{Y}=$ Variabel dependen

$\mathrm{X}=$ Variabel independen

$\mathrm{a}=$ Koefisien.

Nilai $a_{1}$ harus positif dan lebih kecil dari satu agar relevan dengan asumsi Cobb-Douglas. Sehingga berlaku hukum tambahan hasil yang semakin berkurang (the law of diminishing returns) untuk semua variabel X. Perbedaannya dengan fungsi produksi kuadratik dan akar pangkat dua adalah fungsi Cobb-Douglas ini tidak mempunyai nilai maksimum.

Model yang digunakan untuk menganalisis faktor-faktor yang yang mempengaruhi produksi susu sapi perah ditingkat peternak ialah model CobbDouglas di mana terdapat dua variabel yaitu variabel Y sebagai peubah tak bebas (variabel dependen) dalam hal ini adalah produksi susu sapi perah yang dipelihara peternak serta variabel X1, X2, X3, X4 sebagai peubah bebas (variabel independen) yaitu jumlah sapi laktasi, jumlah pemberian pakan hijauan, jumlah pemberian pakan konsentrat dan jumlah pemberian ampas.

Dalam menduga parameter dalam persamaan fungsi Cobb-Douglas maka harus diubah terlebih dahulu ke dalam bentuk double logaritme natural ( $\mathrm{Ln}$ ), bentuk persamaanya menjadi:

$$
\begin{gathered}
\operatorname{Ln} Y=\operatorname{Ln} \beta_{0}+\beta_{1} \operatorname{Ln}_{1}+\beta_{2} \operatorname{Ln}_{2}+\beta_{3} \operatorname{Ln}_{3} \\
+\beta_{4} \operatorname{Ln}_{4}+\varepsilon
\end{gathered}
$$

Keterangan:

$\mathrm{Y}=$ Produktivitas susu sapi perah (liter/ekor/hari)

$\mathrm{X} 1=$ Jumlah sapi laktasi (hari)

$\mathrm{X} 2=$ Jumlah pemberian pakan hijauan (kg/hari)

$\mathrm{X} 3=$ Jumlah pemberian pakan konsentrat $(\mathrm{kg} /$ hari $)$

$\mathrm{X} 4=$ Jumlah pemberian ampas ( $\mathrm{kg} /$ hari)

$\beta 0=$ Konstanta

$\beta 1, \beta 2, \beta 3$ dan $\beta 4=$ Koefisien parameter dugaan $X 1, X 2$, $\mathrm{X} 3$ dan X4

$\varepsilon=$ eror.

Faktor-faktor produksi yang digunakan di atas diperoleh dari penelitan terdahulu, data historis dan disesuaikan dengan kondisi di lapang yang terkait dengan faktor-faktor yang mempengaruhi produksi.

Adapun hipotesis penelitian adalah sebagai berikut: 
1. $\beta_{1}>0$ artinya apabila semakin banyak jumlah sapi laktasi maka produksi susu sapi perah akan semakin meningkat.

2. $\beta_{2}>0$ artinya apabila semakin banyak pemberian pakan hijauan maka produksi susu sapi perah akan semakin meningkat.

3. $\beta_{3}>0$ artinya apabila semakin banyak pemberian konsentrat maka produksi susu sapi perah akan semakin meningkat.

4. $\beta_{4}>0$ artinya apabila semakin banyak pemberian pakan ampas maka produksi susu sapi perah akan semakin meningkat.

Taraf nyata yang digunakan dalam penelitian ini yaitu pada taraf nyata 15 persen.

\section{HASIL DAN PEMBAHASAN}

Faktor-faktor yang Mempengaruhi Produksi Susu Sapi Perah

Setiap usaha yang dijalankan bertujuan untuk mencapai keuntungan yang maksimal. Begitu juga pada usaha ternak sapi perah, peternak pasti menginginkan hasil yang maksimal bagi usahanya. Maka perlu dipahami mengenai faktorfaktor apa saja yang dapat mempengaruhi produksi susu sapi perah.

Berdasarkan hasil pengolahan data (dapat dilihat pada Lampiran 2) dengan menggunakan software EViews 7 diperoleh model fungsi produksi:

$$
\begin{gathered}
Y=-479,6199+288,7596 X_{1}+0,2681 \\
X_{2}+0,1233 X_{3}+0,4159 X_{4}
\end{gathered}
$$

Model penduga fungsi produksi yang telah dilakukan analisis dapat menunjukkan adanya tingkat kelayakan berdasarkan asumsi OLS (Ordinary Least Square) yaitu dengan mencari koefisien model melalui pengepasan (fitting) antara model dengan data sampel. Sehingga mendapat estimasi yang BLUE (Best Linear Unbiased Estimator).

Adapun asumsi OLS yang dimaksud adalah model linier dalam parameter, tidak terdapat autokorelasi, tidak terdapat multikolinier antara variabel independen, ragamnya homogen (homoskedastisitas) dan data menyebar normal (normalitas). Model linier dalam koefisien (parameter) dapat dilihat dari hasil output dimana parameter berderajad satu (berpangkat satu). Pengujian multikolinearitas dilakukan agar variabel independen yang digunakan tidak saling mempengaruhi satu sama lain. Pengujian heteroskedastisitas pada model dengan menggunakan pendekatan plot data. Pengujian terhadap normalitas terlihat dari histogram bahwa data menyebar normal atau pada nilai Jarque-Bera dimana nilai P-value $>\alpha$ membuktikan bahwa sebaran data menyebar normal. Pengujian tersebut dapat dilihat pada Lampiran 3, 4 dan 5. Syarat asumsi OLS terpenuhi dan hal tersebut menunjukkan bahwa model fungsi produksi tersebut dapat digunakan dalam menduga hubungan antara variabel bebas (input produksi) yang digunakan terhadap hasil produksi (output) dalam kegiatan usaha ternak sapi perah.

Hasil pendugaan model dengan menggunakan model fungsi regresi berganda diperoleh bahwa nilai koefisien determinasi (R-squared) sebesar 97,70 persen dengan nilai determinasi ter- 
koreksi (Adjusted R-squared) sebesar 97,36 persen. Nilai koefisien determinasi (R-squared) tersebut menunjukkan bahwa sebesar 97,70 persen dari variasi produksi dapat dijelaskan secara bersama-sama oleh faktor jumlah sapi laktasi, jumlah pemberian pakan hijauan, jumlah pemberian konsentrat dan jumlah pemberian pakan ampas. Sedangkan 2,3 persen lagi dijelaskan oleh faktor-faktor lain diluar model.

Dengan hipotesis penelitian penulis telah terbukti bahwa:

1. Jumlah sapi laktasi berpengaruh positif dan nyata pada taraf nyata 15 persen terhadap produksi susu sapi perah peternak.

2. Pemberian pakan hijauan berpengaruh positif dan nyata pada taraf nyata 15 persen terhadap produksi susu sapi perah peternak.

3. Pemberian konsentrat berpengaruh positif dan tidak nyata pada taraf nyata 15 persen terhadap produksi susu sapi perah peternak.

4. Pemberian pakan ampas berpengaruh positif dan nyata pada taraf nyata 15 persen terhadap produksi susu sapi perah peternak.

Nilai koefisien dalam model fungsi regresi berganda merupakan nilai elastisitas produksi dari variabel-variabel produksi tersebut. Berdasarkan hasil output pada Lampiran 2, maka pengaruh masing-masing variabel bebas terhadap produksi susu dapat diuraikan sebagai berikut:

1. Faktor Jumlah Sapi Laktasi (X1)

Jumlah sapi laktasi yang dimiliki peternak akan menentukan berapa jumlah produksi susu suatu usaha peternakan sapi perah. Rata-rata jumlah kepemilikan sapi laktasi peternak ialah 7 sampai 8 ekor. Kepemilikan sapi perah di Indonesia kurang dari atau sama dengan 10 ekor perpeternak (Yusdja, 2005; Harmini et al., 2012; Atmakusuma, 2012). Rendahnya jumlah kepemilikan sapi laktasi tersebut disebabkan oleh kendala yang dimiliki peternak berupa modal. Hal tersebut sesuai dengan pernyataan Karuniawati (2012).

Variabel jumlah sapi laktasi mempunyai pengaruh nyata terhadap produksi susu sapi peternak. Berdasarkan nilai koefisien parameter faktor jumlah sapi laktasi mempunyai nilai positif yaitu sebesar 288,7596. Nilai tersebut menunjukkan bahwa apabila jumah sapi laktasi bertambah sebesar satu persen maka akan meningkatkan produksi susu sapi perah sebesar 288,7596 persen dengan mengganggap faktor lain tetap (cateris paribus). Pernyataan tersebut sesuai dengan hipotesis sebelumnya yang menyatakan bahwa penambahan jumlah sapi laktasi akan meningkatkan produksi sapi perah serta senada dengan pernyataan Mukson et al. (2009), Anisa (2008) dan Astuti et al. (2010).

2. Faktor Jumlah Pemberian Pakan Hijauan (X2)

Pakan hijauan merupakan pakan utama bagi sapi perah. Hijauan mempunyai kandungan energi relatif rendah namun merupakan sumber vitamin dan mineral yang baik untuk ternak sapi perah. Rata-rata pemberian pakan hijauan kepada sapi perah oleh peternak sebesar 44,34 kilogram 
persatuan ternak perhari. Pemberian pakan hijauan tersebut tidak jauh berbeda di wilayah kerja KPSBU Lembang yaitu sebesar 43,30 kilogram persatuan ternak perhari (Anisa, 2008). Berbeda dengan hasil penelitian Karuniawati (2012) di Kabupaten Bogor bahwa pemberian pakan hijauan kepada sapi perah hanya sebesar 38,69 kilogram persatuan ternak perhari.

Variabel hijauan mempunyai pengaruh nyata terhadap produksi susu sapi perah. Berdasarkan nilai koefisien parameter pemberian pakan hijauan mempunyai nilai positif yaitu sebesar 0,2681. Nilai tersebut menunjukkan bahwa apabila pemberian pakan hijauan bertambah sebesar satu persen maka akan meningkatkan produksi susu sapi perah sebesar 0,2681 persen dengan menganggap faktor lain tetap (cateris paribus). Pernyataan tersebut sesuai dengan hipotesis sebelumnya yang menyatakan bahwa penambahan jumlah sapi laktasi akan meningkatkan produksi sapi perah serta senada dengan pernyataan Heriyanto (2009), Alpian (2010), Apriani (2011) dan Karuniawati (2012).

\section{Faktor Jumlah Pemberian Konsentrat (X3)}

Konsentrat merupakan makanan penguat ternak yang berasal dari bijibijian dan limbah pertanian seperti jagung, menir, bulgur, hasil ikutan pertanian dari pabrik seperti dedak, katul, bungkil kelapa, bungkil kacang tanah dan molases. Peternak memberikan konsentrat kepada sapi perah rata-rata sebesar 5,09 kilogram persatuan ternak perhari. Pemberian konsentrat tersebut tidak jauh berbeda pada peternakan di Kabupaten Bogor yaitu 6,26 kilogram persatuan ternak perhari (Karuniawati, 2012). Berbeda dengan hasil penelitian Anisa (2008) di wilayah kerja KPSBU Lembang bahwa pemberian konsentrat kepada sapi perah sebesar 9,56 kilogram persatuan ternak perhari.

Variabel konsentrat tidak berpengaruh nyata secara statistik terhadap produksi susu sapi perah. Sedangkan berdasarkan nilai koefisien parameter pemberian konsentrat mempunyai nilai positif yaitu sebesar 0,1233. Nilai koefisien regresi tersebut mengandung arti bahwa apabila terjadi penambahan faktor produksi berupa konsentrat sebesar satu persen maka akan meningkatkan produksi sapi perah sebanyak 0,1233 persen dengan menganggap faktor lain tetap (ceteris paribus). Pernyataan tersebut sesuai dengan hipotesis sebelumnya yang menyatakan bahwa penambahan konsentrat sebanyak satu persen akan meningkatkan produksi susu sapi perah namun tidak signifikan secara statistik. Hal tersebut senada dengan pernyataan Mukson et al. (2009), Karuniawati (2012) dan Anisa (2008).

Peternak di Kelurahan Kebon Pedes tidak memiliki takaran yang jelas dalam pemberian konsentrat. Konsentrat diberikan secara asal-asalan oleh peternak bahkan ada peternak yang tidak memberikan konsentrat pada sapi laktasinya. Konsentrat adalah jenis pakan yang mengandung energi dan protein yang tinggi dan serat kasar rendah (Ako, 2013). Sehingga pemberian konsentrat akan mempengaruhi kualitas susu dan bukan 
kepada kuantitas produksi susu sapi perah tersebut.

4. Faktor Jumlah Pemberian Pakan Ampas (X4)

Pakan ampas merupakan limbah yang berasal dari pembuatan tahu dan tempe yang dapat dimanfaatkan sebagai pakan tambahan bagi ternak sapi perah. Peternak memberikan pakan ampas kepada sapi perah dengan rata-rata sebesar 6,53 kilogram persatuan ternak perhari. Pemberian pakan ampas tersebut tidak jauh berbeda pada peternakan di Kabupaten Bogor yaitu sebesar 7,47 kilogram persatuan ternak perhari (Karuniawati, 2012). Berbeda dengan hasil penelitian Anisa (2008) di wilayah kerja KPSBU Lembang bahwa pemberian pakan ampas kepada sapi perah sebesar 14,75 kilogram persatuan ternak perhari.

Variabel pakan ampas berpengaruh nyata terhadap produksi susu sapi perah. Sedangkan berdasarkan nilai koefisien regresi faktor produksi pakan ampas mempunyai nilai positif yaitu sebesar 0,4159. Nilai koefisien regresi tersebut mengandung arti bahwa apabila terjadi penambahan faktor produksi berupa pakan ampas sebesar satu persen maka akan meningkatkan produksi sapi perah sebanya 0,4159 persen dengan menganggap faktor lain tetap (ceteris paribus). Pernyataan tersebut sesuai dengan hipotesis sebelumnya yang menyatakan bahwa penambahan pakan berupa ampas sebanyak satu satuan akan meningkatkan produksi susu sapi perah serta senada dengan pernyataan Anisa (2008) dan Alpian (2010).

\section{Kinerja Usaha Ternak Sapi Perah}

Kinerja atau performance adalah hasil kerja yang dapat dicapai oleh seseorang atau sekelompok orang dalam suatu organisasi baik secara kuantitatif maupun kualitatif yang dalam penelitian ini pada kedua kelompok ternak. Pengukuran kinerja usaha ternak dari kedua kelompok ternak adalah dengan menghitung dan membandingkan tingkat pendapatan dan rasio R/C (Return Cost Ratio) yang dihasilkan dalam usaha ternak sapi perahnya.

\section{Penerimaan Usaha Ternak Sapi Perah}

Penerimaan usaha ternak merupakan nilai produksi yang diperoleh dalam jangka waktu tertentu. Penerimaan usaha ternak merupakan hasil perkalian antara jumlah produksi total susu segar dengan harga jual dari hasil produksi tersebut. Penerimaan usaha ternak sapi perah terdiri atas penerimaan tunai dan penerimaan tidak tunai. Penerimaan tunai berasal dari penjualan susu ke konsumen secara langsung, ke loper dan ke KPS Bogor. Penerimaan tidak tunai berasal dari susu yang diberikan ke pedet. Penelitian ini hanya membahas mengenai penerimaan usaha ternak pada sapi laktasi atau sapi produksi saja.

Rata-rata harga jual susu segar peternak di Kelompok Ternak Maju Terus sebesar Rp 6.867 per liter. Sedangkan harja jual susu segar peternak di Kelompok Ternak Sumber Makmur sebesar Rp 5.045 per liter nya. Rata-rata penerimaan total peternak di Kelompok Ternak Maju Terus adalah sebesar Rp 2.582.953,38 sedangkan rata-rata penerimaan total peternak di Kelompok 
Ternak Sumber Makmur adalah sebesar Rp 1.729.627,80.

\section{Struktur Biaya Usaha Ternak Sapi Perah}

Biaya usaha ternak sapi perah terdiri dari dua komponen, yaitu biaya tunai dan biaya yang diperhitungkan. Biaya tunai meliputi jumlah uang yang dibayarkan untuk pembelian barang dan jasa bagi usaha ternak. Sedangkan biaya yang diperhitungkan meliputi pengeluaran tidak tunai yang dikeluarkan oleh peternak sebagai opportunity cost lahan milik pribadi, tenaga kerja dalam keluarga dan penyusutan dari sarana produksi (Soekartawi et al., 1986).

Biaya tunai dalam usaha ternak sapi perah terdiri dari biaya pembelian pakan hijauan, konsentrat, pakan ampas, mineral, pelicin ambing, obat-obatan dan vitamin, tenaga kerja luar keluarga, transportasi, listrik, dan biaya iuran koperasi. Biaya tunai tersebut dikeluarkan sesuai dengan jumlah ternak yang dimiliki peternak. Biaya listrik dan iuran koperasi merupakan biaya yang bersifat tetap yang harus dikeluarkan oleh peternak. Biaya tetap adalah biaya yang relatif tetap jumlahnya, dan terus dikeluarkan walaupun produksi yang diperoleh banyak atau sedikit. Total biaya tunai pada Kelompok Ternak Maju Terus sebesar Rp 864.158,85 dan total biaya tunai pada Kelompok Ternak Sumber Makmur sebesar Rp 924.862,18.

Biaya diperhitungkan terdiri dari biaya upah tenaga kerja dalam keluarga, penyusutan kandang, penyusutan peralatan dan biaya sewa lahan untuk kandang. Total biaya yang diperhitungkan pada
Kelompok Ternak Maju Terus Rp $320.216,38$ sedangkan total biaya yang diperhitungkan sebesar Rp 347.160,71. Sehingga dapat disimpulkan bahwa persentase biaya tunai lebih dominan dibandingkan dengan biaya yang diperhitungkan.

Jumlah biaya total merupakan penjumlahan dari total biaya tunai dan total biaya yang diperhitungkan. Jumlah biaya total pada Kelompok Maju Terus sebesar Rp 1.184.375,23 sedangkan pada Kelompok Sumber Makmur sebesar Rp 1.272.022,89.

\section{Pendapatan dan $\mathrm{R} / \mathrm{C}$ rasio Usaha Ternak Sapi Perah}

Pendapatan usaha ternak diperoleh dari selisih antara penerimaan dengan biaya yang dikeluarkan dalam kegiatan usaha ternak tersebut. Pendapatan dibedakan menjadi dua macam yaitu pendapatan atas biaya tunai dan pendapatan atas biaya total.

Rata-rata pendapatan atas biaya tunai untuk satu ekor sapi laktasi pada bulan Januari 2014 pada peternak di Kelompok Ternak Maju Terus sebesar Rp 1.718.794,53 sedangkan rata-rata pendapatan atas total biayanya sebesar Rp 1.398.578,15. Rata-rata pendapatan peternak di Kelompok Ternak Maju terus lebih tinggi dibandingkan peternak di Kelompok Ternak Sumber Makmur yang memiliki rata-rata pendapatan atas biaya tunai untuk satu ekor sapi laktasi pada bulan Januari tahun 2014 sebesar Rp $804.765,62$ dan rata-rata pendapatan atas biaya total adalah sebesar Rp 457.604,91.

Rata-rata hasil perhitungan analisis rasio $\mathrm{R} / \mathrm{C}$ atas biaya tunai untuk satu ekor 
sapi laktasi pada peternak di Kelompok Ternak Maju Terus adalah 2,99. Nilai tersebut mempunyai arti bahwa setiap pengeluaran tunai sebesar $\mathrm{Rp} 1$, akan menghasilkan penerimaan sebesar $\mathrm{Rp}$ 2,99. Sedangkan rata-rata rasio $\mathrm{R} / \mathrm{C}$ atas biaya total untuk satu ekor sapi laktasi di Kelompok Ternak Maju Terus ini sebesar 2,18. Nilai tersebut mempunyai arti bahwa setiap Rp 1 biaya total yang dikeluarkan peternak memperoleh penerimaan sebesar Rp 2,18. Pada peternak di Kelompok Ternak Sumber Makmur, ratarata rasio $\mathrm{R} / \mathrm{C}$ atas biaya tunai untuk satu ekor sapi laktasi adalah 1,87. Nilai ini mempunyai arti bahwa setiap Rp 1 biaya tunai, akan menghasilkan penerimaan sebesar Rp 1,87. Sedangkan rata-rata rasio $\mathrm{R} / \mathrm{C}$ atas biaya total untuk satu ekor sapi laktasi adalah 1,36. Nilai tersebut mempunyai arti bahwa setiap pengeluaran biaya tunai sebesar $\mathrm{Rp} 1$, akan menghasilkan penerimaan sebesar $\mathrm{Rp}$ 1,36. Hasil perhitungan analisis pendapatan dan rasio $\mathrm{R} / \mathrm{C}$ dapat dilihat pada Lampiran 6 dan 7.

Berdasarkan hasil tingkat pendapatan dan nilai rasio $\mathrm{R} / \mathrm{C}$ di kedua kelompok ternak tersebut maka dapat dilihat bahwa kinerja Kelompok Ternak Maju Terus lebih baik karena memiliki nilai pendapatan dan nilai rasio $\mathrm{R} / \mathrm{C}$ yang lebih tinggi dibandingkan dengan kinerja di Kelompok Ternak Sumber Makmur. Peternak Kelompok Ternak Maju terus memiliki nilai rasio $\mathrm{R} / \mathrm{C}$ atas biaya tunai untuk satu ekor sapi laktasi adalah 2,99 dan rasio $\mathrm{R} / \mathrm{C}$ atas biaya total untuk satu ekor sapi laktasi adalah 2,18. Sedangkan di Kelompok Ternak Sumber Makmur, nilai rasio $\mathrm{R} / \mathrm{C}$ atas biaya tunai untuk satu ekor sapi laktasi adalah 1,87 dan nilai rasio $\mathrm{R} / \mathrm{C}$ atas biaya total untuk satu ekor sapi laktasi adalah 1,36. Adapun hasil penelitian Karuniawati (2012) pada peternak Kelompok Ternak Mekar Jaya, Desa Cipayung, Kecamatan Megamendung, Kabupaten Bogor yang memiliki rata-rata kepemilikan sapi perah laktasi sebesar lima ekor per peternak dengan rata-rata produktivitas susu 8-10 liter/ ekor/hari dan rata-rata pendapatan atas biaya tunai sebesar $\mathrm{Rp}$ 458.980,68 dan pendapatan atas biaya total sebesar $\mathrm{Rp}$ 238.994,15 serta nilai rasio $\mathrm{R} / \mathrm{C}$ atas biaya tunai sebesar 1,64 dan nilai rasio $\mathrm{R} / \mathrm{C}$ atas biaya total sebesar 1,25.

Apabila kinerja ketiga kelompok ternak tersebut dibandingkan maka dapat dilihat bahwa kinerja Kelompok Ternak Maju Terus lebih baik karena memiliki nilai $\mathrm{R} / \mathrm{C}$ rasio tertinggi. Selanjutnya kinerja Kelompok Ternak Sumber Makmur juga lebih baik dibandingkan kinerja Kelompok Ternak Mekar Jaya yang ditandai oleh lebih tingginya nilai rasio R/C yang dihasilkan. Namun, ketiga kelompok ternak tersebut sudah memiliki usaha ternak sapi perah yang menguntungkan. Hal tersebut dapat dilihat dari nilai rasio $\mathrm{R} / \mathrm{C}$ ketiga kelompok tersebut memiliki nilai yang lebih besar dari satu, namun bila dilihat dari rendahnya tingkat pendapatan peternak maka usaha ternak tersebut belum dapat dikatakan ekonomis dari segi bisnis.

\section{Simpulan}

1. Faktor-faktor yang mempunyai pengaruh signifikan terhadap produksi susu sapi perah pada peternak di 
Kelurahan Kebon Pedes, Kota Bogor adalah jumlah sapi laktasi, jumlah pemberian pakan hijauan dan jumlah pemberian pakan ampas. Sedangkan faktor konsentrat tidak mempunyai pengaruh nyata terhadap produksi susu. Penambahan jumlah sapi laktasi, penggunaan pakan hijauan, konsentrat, pakan ampas merupakan faktor yang dapat meningkatkan produksi susu.

2. Rata-rata tingkat pendapatan usaha ternak atas biaya tunai per ekor sapi laktasi peternak di Kelompok Ternak Maju Terus sebesar Rp 1.718.794,53 sedangkan pendapatan rata-rata atas biaya total sebesar $\mathrm{Rp}$ 1.398.578,15 per ekor sapi laktasi dengan nilai $\mathrm{R} / \mathrm{C}$ ratio atas biayatunai sebesar 2,99 dan atas biaya total sebesar 2,18. Rata-rata tingkat pendapatan usaha ternak atas biaya tunai per ekor sapi laktasi peternak di Kelompok Ternak Sumber Makmur sebesar Rp 804.765,62 sedangkan pendapatan rata-rata atas biaya total sebesar Rp 457.604,91 per ekor sapi laktasi dengan nilai $\mathrm{R} / \mathrm{C}$ ratio atas biaya tunai sebesar 1,87 dan atas biaya total sebesar 1,36. Nilai tersebut menunjukkan bahwa usaha ternak sapi perah yang diusahakan peternak di kedua kelompok ternak sudah menguntungkan. Namun, berdasarkan hasil analisis $\mathrm{R} / \mathrm{C}$ rasio di kedua kelompok ternak tersebut maka dapat dilihat bahwa kinerja Kelompok Ternak Maju Terus lebih baik karena memiliki nilai $\mathrm{R} / \mathrm{C}$ rasio yang lebih tinggi dibandingkan dengan kinerja di Kelompok Ternak Sumber Makmur.

\section{Saran}

Saran yang diberikan adalah peternak perlu meningkatkan jumlah kepemilikan sapi laktasi, kuantitas dan kualitas pakan hijauan, konsentrat dan pakan ampas dengan tepat agar produktivitas produksi susu sapi meningkat. Karena faktor tersebut diduga mempengaruhi produksi susu sapi perah.

Pemberian pakan tersebut harus dilakukan dengan takaran yang benar (bukan asal-asalan) karena hal ini akan berdampak pada pemborosan biaya pakan. Untuk penelitian selanjutnya, faktor sumberdaya manusia sebagai pengelola usaha ternak perlu dikaji secara mendalam serta menambah variabel lainnya karena faktor tersebut dapat meningkatkan produktivitas sapi perah sehingga meningkatkan kinerja usaha.

\section{DAFTAR PUSTAKA}

Ako, Ambo. 2013. Ilmu Ternak Perah Daerah Tropis. IPB Press. Bogor.

Alpian. 2010. Faktor-Faktor yang Mempengaruhi Produktivitas Susu dan Pendapatan Peternak Sapi Perah di Kecamatan Tanjungsari, Kabupaten Sumedang. [Skripsi]. Program Sarjana. Institut Pertanian Bogor, Bogor.

Anisa, Anis. 2008. Analisis Fungsi Biaya dan Efisiensi Usahaternak Sapi Perah di Wilayah Kerja KPSBU Lembang Kabupaten Bandung. [Skripsi]. Program Sarjana. Institut Pertanian Bogor, Bogor.

Apriani. 2011. Analisis Faktor-Faktor yang Mempengaruhi Produktivitas Susu Sapi pada CV Mulya Khansa Niaga di Kota Depok, Jawa Barat. 
[Skripsi]. Program Sarjana. Institut Pertanian Bogor, Bogor.

Astuti, Melani, Rini Widiati dan Yustina Yuni Suranindyah. 2010. Efisiensi Produksi Usaha Sapi Perah Rakyat (Studi Kasus pada Peternak Anggota Koperasi Usaha Peternakan dan Pemerahan Sapi Perah Kaliurang, Sleman, Yogyakarta). Buletin Peternakan, 34(1): 64-69.

Atmakusuma, Juniar. 2012. Kelayakan Usaha Peternakan Sapi Perah dalam Menunjang Swasembada Susu di Indonesia. Prosiding Seminar Penelitian Unggulan Departemen Agribisnis. ISBN 978979-19423-8-6. Bogor, 27-28 Desember 2012.

[BPS] Badan Pusat Statistik Indonesia. 2014. Kontribusi Sub Sektor Pertanian Terhadap PDB di Indonesia dari Tahun 2004 sampai 2012. $\quad$ http://www.bps.go.id. Diakses 17 Januari 2014.

Debertin, David L. 1986. Agricultural Production Economics. Macmillan Publishing Company. Unites States of America.

[Deptan] Departemen Pertanian. 2014. Populasi Ternak di Indonesia Tahun 2006 sampai 2011. http://www.deptan.go.id. Diakses 27 Januari 2014.

[Ditjennak]. Direktorat Jendral Peternakan. 2014. Perkembangan Tingkat Konsumsi Susu di Indonesia Tahun 2006 sampai 2010.

http://ditjennak.pertanian.go.id/. Diakses 28 Januari 2014.
Harmini, Ratna Winandi Asmarantaka, Dwi Rachmina dan Feryanto. 2012. Analisis Kelayakan Usaha Ternak Sapi Perah Rakyat dan Pemasaran Susu di Jawa Timur (Studi Kasus Peternakan Sapi Perah di Kecamatan Pujon, Malang-Jawa Timur). Proseding Seminar Penelitian Unggulan Departemen Agribisnis. ISBN 978979-19423-8-6. Bogor, 27-28 Desember 2012

Heriyanto. 2009. Analisis Pendapatan dan Faktor yang Mempengaruhi Produksi Susu Sapi Perah di Tingkat Peternak (Kasus Anggota Koperasi Serba Usaha "Karya Nugraha" kecamatan Cigugur Kabupaten Kuningan Provinsi Jawa Barat). [Skripsi]. Program Sarjana. Institut Pertanian Bogor, Bogor.

Karuniawati, Rina. 2012. Faktor-faktor yang Mempengaruhi Produksi Susu Sapi Perah (Kasus Peternak Anggota Kelompok Ternak Mekar Jaya Desa Cipayung, Kecamatan Megamendung, Kabupaten Bogor, Provinsi Jawa Barat). [Skripsi]. Program Sarjana. Institut Pertanian Bogor, Bogor.

Moeheriono. 2010. Pengukuran Kinerja Berbasis Kompetensi. Ghalia Indonesia, Bogor.

Mukson, T. Ekowati, M. Handayani dan D.W. Harjanti. 2009. FaktorFaktor yang Mempengaruhi Kinerja Usaha Ternak Sapi Perah Rakyat di Kecamatan Getasan Kabupaten Semarang. Seminar Nasional Kebangkitan Peternakan. Semarang, 20 Mei 2009. 
Nicholson, Walter. 2000. Intermediate

Microeconomics and Its

Application. Eight Edition.

Harcourt Inc.

Soekartawi, A. Soeharjo, Dillon JL, Hardaker JB. 1986. Ilmu Usahatani dan Penelitian Untuk Pengembangan Petani Kecil. UI Press. Jakarta.

Soekartawi. 2002. Analisis Usahatani. UI Press. Jakarta.

Semaoen, I dan Siti MK. 2011. Mikroekonomi. UB Press. Malang.

Sudarsono. 1995. Pengantar Ekonomi Mikro. LP3ES. Jakarta.

Sudono, A. 1999. Ilmu Produksi Ternak Perah. Institut Pertanian Bogor. Bogor

Wahyudi, Ahmad. 2014. Analisis FaktorFaktor yang Mempengaruhi Pendapatan Anggota Koperasi Peternakan Sapi Perah (Studi Kasus pada Anggota "SAE Kecamatan Pujon, Kabupaten Malang). Jurnal Ilmiah. Universitas Brawijaya. Malang. 
Lampiran 1. Populasi Ternak (000 ekor) tahun 2010 sampai 2013

\begin{tabular}{lrrrr}
\hline Kegiatan Utama & $\mathbf{2 0 1 0}$ & $\mathbf{2 0 1 1}$ & $\mathbf{2 0 1 2}$ & $\mathbf{2 0 1 3}$ \\
\hline Sapi Potong & 13.582 & 14.824 & 15.981 & 16.607 \\
Sapi Perah & 488 & 597 & 612 & 636 \\
Kerbau & 2.000 & 1.305 & 1.438 & 1.484 \\
Kuda & 419 & 409 & 437 & 454 \\
Kambing & 16.620 & 16.946 & 17.906 & 18.576 \\
Domba & 10.725 & 11.791 & 1.420 & 14.560 \\
Babi & 7.477 & 7.525 & 7.900 & 8.246 \\
Ayam Buras & 257.544 & 264.340 & 274.564 & 290.455 \\
Ayam Ras Petelur & 105.210 & 124.636 & 138.718 & 147.279 \\
Ayam Ras Pedaging & 986.872 & 1.177 .991 & 1.244 .402 & 1.355 .288 \\
Itik & 44.302 & 43.488 & 49.295 & 50.931 \\
\hline
\end{tabular}

Catatan: *Angka Sementara

Sumber: BPS (2014)

\section{Lampiran 2. Kutipan Hasil Olahan Data Dengan Software EViews 7}

Dependent Variable: PRODUKSI_SUSU

Method: Least Squares

Date: 03/23/14 Time: 22:19

Sample: 132

Included observations: 32

\begin{tabular}{lllll}
\hline \hline Variable & Coefficient & Std. Error & t-Statistic & Prob. \\
\hline \hline C & -479.6199 & 238.1598 & -2.013858 & 0.0541 \\
SAPI_LAKTASI & 288.7596 & 8.741439 & 33.03342 & 0.0000 \\
HIJAUAN & 0.268125 & 0.169741 & 1.579610 & 0.1258 \\
KONSENTRAT & 0.123297 & 0.676729 & 0.182196 & 0.8568 \\
PAKAN_AMPAS & 0.415985 & 0.226157 & 1.839359 & 0.0769 \\
\hline \hline & & & \\
R-squared & 0.977040 & Mean dependent var & 2160.671 \\
Adjusted R-squared & 0.973639 & S.D. dependent var & 2406.828 \\
S.E. of regression & 390.7768 & Akaike info criterion & 14.91675 \\
Sum squared resid & 4123077. & Schwarz criterion & 15.14577 \\
Log likelihood & -233.6680 & Hannan-Quinn criter. & 14.99267 \\
F-statistic & 287.2411 & Durbin-Watson stat & 2.034127 \\
Prob(F-statistic) & 0.000000 & & \\
\hline \hline
\end{tabular}




\section{Lampiran 3. Statistik VIF}

Variance Inflation Factors

Date: 03/23/14 Time: 22:46

Sample: 132

Included observations: 32

\begin{tabular}{llll}
\hline \hline Variable & $\begin{array}{l}\text { Coefficient } \\
\text { Variance }\end{array}$ & $\begin{array}{l}\text { Uncentered } \\
\text { VIF }\end{array}$ & $\begin{array}{l}\text { Centered } \\
\text { VIF }\end{array}$ \\
\hline \hline C & 56720.08 & 11.88582 & NA \\
SAPI_LAKTASI & 76.41276 & 1.842935 & 1.022906 \\
HIJAUAN & 0.028812 & 3.803905 & 1.070151 \\
KONSENTRAT & 0.457962 & 1.432459 & 1.062292 \\
PAKAN_AMPAS & 0.051147 & 10.30277 & 1.084840 \\
\hline \hline
\end{tabular}

\section{Lampiran 4. Hasil Pengolahan Pengujian Heteroskedastisitas Fungsi Produksi}

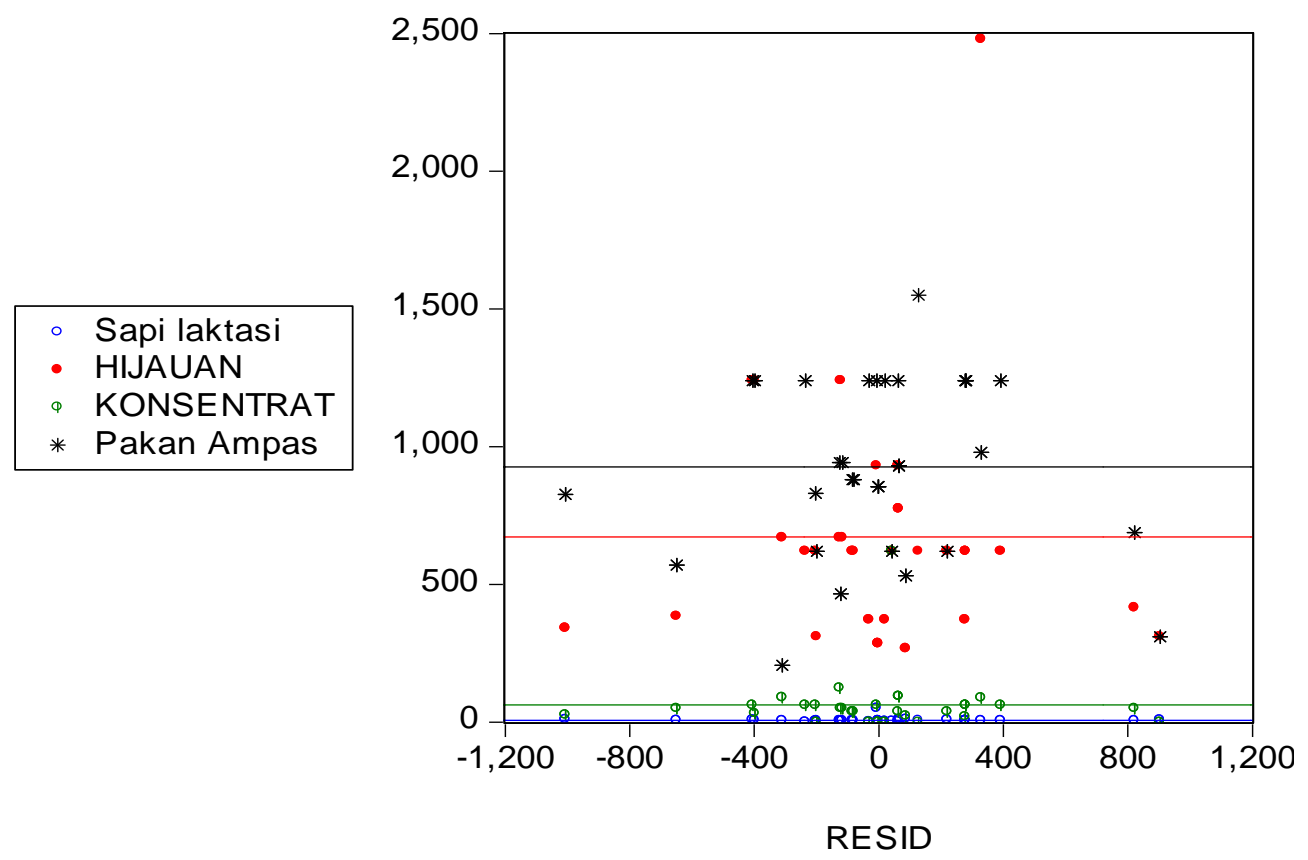




\section{Lampiran 5. Grafik Sebaran Data Penelitian}

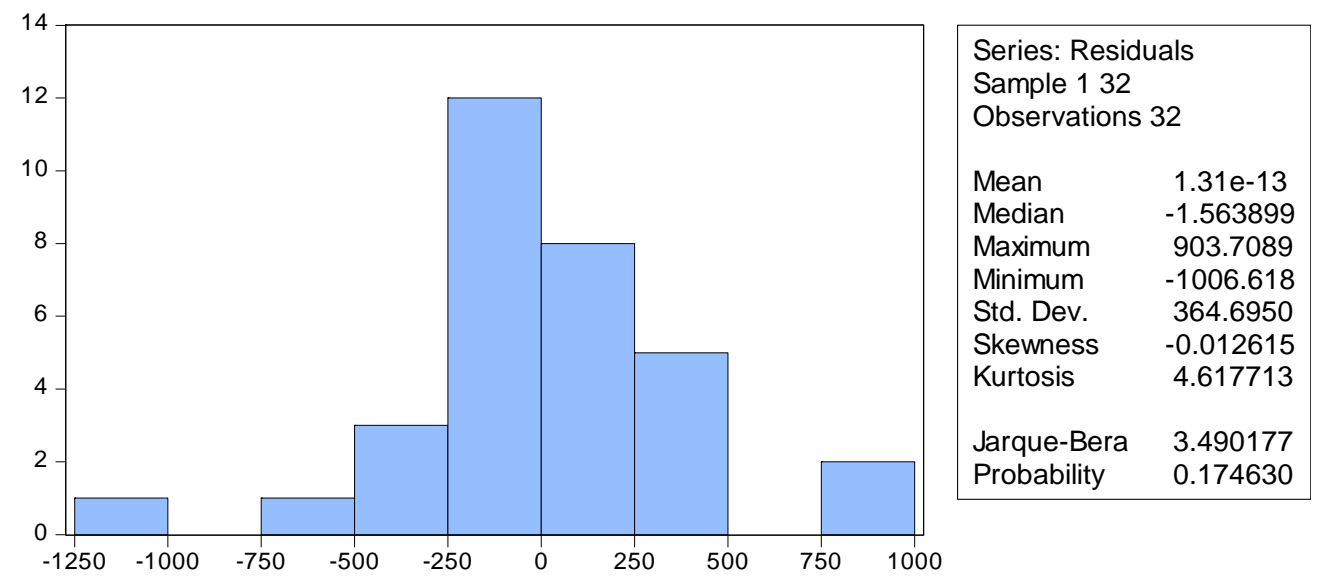


Lampiran 6. Kinerja Usaha Ternak Sapi Perah Per Ekor Laktasi di Kelompok Ternak Maju Terus Bulan Januari Tahun 2014

\begin{tabular}{|c|c|c|c|c|c|}
\hline \multirow{2}{*}{ No } & \multirow{2}{*}{ Komponen } & \multicolumn{4}{|c|}{ Kelompok Ternak Maju Terus } \\
\hline & & Jumlah & Satuan & Harga (Rp) & Nilai (Rp) \\
\hline \multirow[t]{8}{*}{1} & Penerimaan Usahaternak & & & & \\
\hline & A. Penerimaan Tunai & & & & \\
\hline & Penjualan Susu & 314,14 & Liter & 6.867 & $2.157 .199,38$ \\
\hline & Total Penerimaan Tunai & & & & 2.157.199,38 \\
\hline & B. Pendapatan Non Tunai & & & & \\
\hline & Susu untuk pedet & 62,00 & Liter & 6.867 & $425.754,00$ \\
\hline & Total Penerimaan Non Tu & nai & & & $425.754,00$ \\
\hline & Total Penerimaan $(\mathrm{A}+\mathrm{B})$ & & & & 2.582.953,38 \\
\hline \multirow[t]{20}{*}{2} & \multicolumn{5}{|l|}{ Biaya Usahaternak } \\
\hline & \multicolumn{5}{|l|}{ C. Biaya Tunai } \\
\hline & Pakan hijauan & 610,86 & $\mathrm{Kg}$ & 255,26 & $155.928,12$ \\
\hline & Konsentrat & 51,64 & $\mathrm{Kg}$ & $2.282,14$ & $117.849,71$ \\
\hline & Pakan Ampas & 985,14 & $\mathrm{Kg}$ & 446,05 & $439.421,70$ \\
\hline & Mineral & & & & $1.827,59$ \\
\hline & Vitamin/Obat-obatan & & & & $8.000,00$ \\
\hline & Pelicin ambing & 0,17 & $\mathrm{Kg}$ & 24.000 & $4.080,00$ \\
\hline & TKLK & 3,26 & HKP & 25.000 & $81.500,00$ \\
\hline & Transportasi & & & & $39.482,76$ \\
\hline & Listrik & & & & $6.068,97$ \\
\hline & Iuran Koperasi & & & & $10.000,00$ \\
\hline & Total biaya tunai & & & & $864.158,85$ \\
\hline & \multicolumn{5}{|l|}{ D. Biaya Diperhitungkan } \\
\hline & TKDK & 6,47 & HKP & 25.000 & 161.750 \\
\hline & Penyusutan Kandang & & & & $35.531,61$ \\
\hline & Penyusutan Peralatan & & & & $37.169,50$ \\
\hline & Sewa Lahan & & & & $85.765,27$ \\
\hline & Total Biaya Diperhitungk & & & & $320.216,38$ \\
\hline & Biaya Total (C+D) & & & & $1.184 .375,20$ \\
\hline 3 & \multicolumn{4}{|c|}{ Pendapatan Atas Biaya Tunai } & $1.718 .794,53$ \\
\hline 4 & \multicolumn{4}{|c|}{ Pendapatan Atas Biaya Total } & $1.398 .578,15$ \\
\hline 5 & \multicolumn{4}{|l|}{ R/C Ratio Tunai } & 2,99 \\
\hline 6 & \multicolumn{4}{|l|}{ R/C Ratio Total } & 2,18 \\
\hline
\end{tabular}


Lampiran 7. Kinerja Usaha Ternak Sapi Perah Per Ekor Laktasi di Kelompok Sumber Makmur Bulan Januari Tahun 2014

\begin{tabular}{|c|c|c|c|c|c|}
\hline \multirow{2}{*}{ No } & \multirow{2}{*}{ Komponen } & \multicolumn{4}{|c|}{ Kelompok Ternak Sumber Makmur } \\
\hline & & Jumlah & Satuan & Harga (Rp) & Nilai (Rp) \\
\hline \multirow[t]{8}{*}{1} & Penerimaan Usahaternak & & & & \\
\hline & A. Penerimaan Tunai & & & & \\
\hline & Penjualan Susu & 280,84 & Liter & 5.045 & $1.416 .837,80$ \\
\hline & Total Penerimaan Tunai & & & & $1.416 .837,80$ \\
\hline & B. Pendapatan Non Tunai & & & & \\
\hline & Susu untuk pedet & 62,00 & Liter & 5.045 & $312.790,00$ \\
\hline & Total Penerimaan Non $\mathrm{T} t$ & & & & $312.790,00$ \\
\hline & Total Penerimaan $(\mathbf{A}+\mathrm{B})$ & & & & $1.729 .627,80$ \\
\hline \multirow[t]{20}{*}{2} & \multicolumn{5}{|l|}{ Biaya Usahaternak } \\
\hline & \multicolumn{5}{|l|}{ C. Biaya Tunai } \\
\hline & Pakan hijauan & 763,55 & $\mathrm{Kg}$ & 219,23 & $167.393,07$ \\
\hline & Konsentrat & 106,20 & $\mathrm{Kg}$ & $2.243,75$ & $238.286,25$ \\
\hline & Pakan Ampas & 842,96 & $\mathrm{Kg}$ & 430,34 & $362.759,41$ \\
\hline & Mineral & & & & 119,05 \\
\hline & Vitamin/Obat-obatan & & & & $12.017,90$ \\
\hline & Pelicin ambing & 0,12 & $\mathrm{Kg}$ & 24.000 & $2.880,00$ \\
\hline & TKLK & 2,78 & HKP & 25.000 & $69.500,00$ \\
\hline & Transportasi & & & & $53.553,57$ \\
\hline & Listrik & & & & $8.352,94$ \\
\hline & Iuran Koperasi & & & & $10.000,00$ \\
\hline & Total biaya tunai & & & & $924.862,18$ \\
\hline & \multicolumn{5}{|l|}{ D. Biaya Diperhitungkan } \\
\hline & TKDK & 7,15 & HKP & 25.000 & $178.750,00$ \\
\hline & Penyusutan Kandang & & & & $28.571,43$ \\
\hline & Penyusutan Peralatan & & & & $46.509,00$ \\
\hline & Sewa Lahan & & & & $93.330,28$ \\
\hline & Total Biaya Diperhitungk & & & & $347.160,71$ \\
\hline & Biaya Total $(\mathrm{C}+\mathrm{D})$ & & & & $1.272 .022,90$ \\
\hline 3 & \multicolumn{4}{|c|}{ Pendapatan Atas Biaya Tunai } & $804.765,62$ \\
\hline 4 & \multicolumn{4}{|c|}{ Pendapatan Atas Biaya Total } & $457.604,91$ \\
\hline 5 & \multicolumn{4}{|c|}{ R/C Ratio Tunai } & 1,87 \\
\hline 6 & \multicolumn{4}{|l|}{ R/C Ratio Total } & 1,36 \\
\hline
\end{tabular}

